Article

\title{
Degradation Kinetics of Anthocyanins in Sour Cherry Cloudy Juices at Different Storage Temperature
}

\author{
Aneta Wojdyło ${ }^{1, *(\mathbb{D}}$, Paulina Nowicka ${ }^{1}$ and Mirosława Teleszko ${ }^{2}$ \\ 1 Department of Fruit, Vegetable and Plant Nutraceutical Technology, Wrocław University of Environmental \\ and Life Sciences, Str. Chełmońskiego 37, 51-630 Wroclaw, Poland; paulina.nowicka@upwr.edu.pl \\ 2 Department of Animal Food Technology, Wroclaw University of Economics, Str. Komandorska 118/120, \\ 53-345 Wroclaw, Poland; miroslawa.teleszko@ue.wroc.pl \\ * Correspondence: aneta.wojdylo@upwr.edu.pl; Tel.: +48-71-320-7706
}

Received: 1 May 2019; Accepted: 31 May 2019; Published: 12 June 2019

\begin{abstract}
The aim of this study was to characterize in detail 25 sour cherry cultivars and provide data on their industrial processing into high-quality sour cherry cloudy juices $(\mathrm{ScCJ})$. Anthocyanin composition was identified and quantified by LC-PDA-ESI-MS QTof, UPLC-PDA. Kinetic degradation $\left(\mathrm{k} \times 10^{3}, \mathrm{t}_{1 / 2}\right.$, D value) and color $\left(\mathrm{CIE} \mathrm{La} \mathrm{b}^{*}\right)$ were measured before and after 190 days of storage at $4{ }^{\circ} \mathrm{C}$ and $30{ }^{\circ} \mathrm{C}$. A total of five anthocyanins, four cyanidins (-3-O-sophoroside, -3-O-glucosyl-rutinoside, -3-O-glucoside, and -3-O-rutinoside) and one peonidin-3-O-rutinoside were detected across all investigated juices. Total anthocyanin content ranged from $\sim 590$ to $\sim 1160 \mathrm{mg} / \mathrm{L}$ of juice, with the highest levels in Skierka, Nagy Erdigymulscu, Wilena, Wiblek, and Safir cvs., and the lowest in Dradem and Nanaones. During 190 days of storage a significant change was observed in the content of anthocyanins. Their degradation depended rather on the storage conditions (time and temperature) than on the type of anthocyanin compounds present in the ScCJ. Half-life values of ScCJ ranged from 64.7 to 188.5 days at $4{ }^{\circ} \mathrm{C}$ and from 45.9 to 112.40 days at $30^{\circ} \mathrm{C}$. Sample redness changed more rapidly than yellowness or lightness and Chroma or hue angel. These results may be useful for the juice industry and serve as a starting point for the development of tasty sour cherry juices with high levels of bioactive compounds.
\end{abstract}

Keywords: Prunus cerasus L.; cloudy juices; LC-PDA-ESI-MS QTof; stability; anthocyanins; half-life periods; color

\section{Introduction}

Sour cherry fruits are primarily cultivated in Europe ( $80 \%$ ) and over $65 \%$ of total world production $(1,215,748,000 \mathrm{t})$ is located there. Major growers are Poland, with a share of $16 \%(201,681,000 \mathrm{t})$, Turkey $15 \%$ (185,435,000 t), Russian Federation 13\% (157,000,000 t), Ukraine, Iran, and the United States. In Poland, sour cherry production represents more than $50 \%$ of all stone fruits, and it is the second most popular fruit grown after apple [1]. Sour cherries are utilized principally by the processing industry as frozen fruits, concentrates, clear juices, jams and marmalades, alcoholic beverages and soft drinks, and especially nectars. So far, the most popular type of liquid product obtained from sour cherry fruits has been a clear juice. Majority of clear juices available at retail sellers contain only minor amounts of polyphenols. During production of clear juices some process i.e., pulp enzymation, clarification, filtration makes a reduction of serum viscosity and eliminates the cloudiness factors then follows the removal of pectin, polysaccharides, and especially phenolic compounds causes significant deterioration in the pro-healthy properties of the clear juice. Therefore, for an alternative to the clear juice production is a natural cloudy juice, rich in phenolic compounds and fiber. In the manufacturing 
process there is no pulp enzymation, filtration, or clarification therefore followed significant behavior of polyphenol compounds and other active substances.

It is pressed directly without an addition of enzymes during mash and clarification steps. Previous studies demonstrated that cloudy juices made from apples, strawberries, and quince contained much more bioactive compounds i.e., polyphenols, vitamins, minerals, and pectins than clear juices [2-4].

Sour cherries are a rich source of health-promoting compounds such as secondary metabolites know as phytochemicals, and of natural antioxidant substances, such as anthocyanins [4-6]. Anthocyanins may also exhibit antioxidant, anti-inflammatory, antiallergic, antiviral, antiproliferative, cardioprotective, anticarcinogenic, and blood-lipid lowering properties [7]. Total content of anthocyanins in different cultivars of sour cherry ranges from 90 to $1000 \mathrm{mg} / 100 \mathrm{~g}$ of fruits [4]. Daily consumption of anthocyanins was recently reported to be $12.5 \mathrm{mg} /$ day in the United States [8] and $82 \mathrm{mg} /$ day in Finland [9]. Such huge differences in estimates of the daily intake were claimed to result from different food intake data [8]. With diverse availability and potential sources of phytochemical modifications throughout processing and storage, a thorough evaluation of changes in anthocyanins and red color due to processing and storage is important for consumers, particularly with regard to recommended daily servings of specific products.

Additionally, red color is one of the most crucial sensory properties of food; therefore, minimization of pigment loss during processing and storage is the most important quality parameter. Many works [5,10-12] showed that anthocyanin stability, apart from food processing, depended on numerous factors including storage temperature, $\mathrm{pH}$, light, the presence of metal ions, oxygen, enzymes, ascorbic acid, sugars, sulfur dioxide or sulfites, and copigments belonging to various compound classes. Also, earlier studies $[3,4]$ indicated significant influence of cultivars on the content of phytochemicals, particularly of phenolic compounds. Despite that, information on the changes in main compounds of sour cherry cloudy juices (ScCJ) being 100\% fruit products is still limited. Kim et al. [12] reported the effects of sour cherry fruit to jam processing on phenolic content and antioxidant activity but no data on the changes in anthocyanins after storage were provided. Toydemir et al. [5] studied the quality of industrially prepared sour cherry nectars. Damar et al. [11] investigated antioxidant capacity and anthocyanin profile of clear sour cherry juices after an enzymatic maceration. However, to the best of our knowledge there have been no reports in the literature about cloudy juices made from sour cherry. Still, data are lacking on the quality and composition of anthocyanins in $\mathrm{ScCJ}$ before and after storage. Additionally, red color stability of $\mathrm{ScCJ}$ is of great interest to food industry and scientists. Considering the above, we decided to investigate the possibilities of cloudy juice production from sour cherry fruits.

Therefore, the aim of this work was to characterize the anthocyanins (by LC-PDA-ESI-MS, UPLC-PDA) of different $25 \mathrm{ScCJs}$ and to determine their stability during 90 and 180 days of storage at different temperatures $\left(4^{\circ} \mathrm{C}\right.$ and $\left.30^{\circ} \mathrm{C}\right)$. To this end, changes in their color and kinetic parameters of anthocyanin degradation were investigated.

\section{Materials and Methods}

\subsection{Chemicals}

All chemicals and reagents were of analytical grade and were supplied from Sigma-Aldrich (Poznań, Poland). All polyphenolic standards were supplied from Extrasynthese (Lyon, France). Water for UPLC analysis was prepared by using an HLP SMART 1000 s system (Hydrolab, Gdańsk, Poland).

\subsection{Plant Material}

Twenty-five different sour cherry (Prunus cerasus L.) cultivars: ('Agat', 'Dradem', 'Erdi botermo', 'Erdi Nagygyümüscu', 'Groniasta', 'Karneol', 'Kelleris 14', 'Lucyna', 'Eutówka', 'Morina', 'Nana', 'North star', 'Pandy 103', 'Sabina', 'Safir', 'Topas', 'Turgieniewka', 'Wanda', 'Wiblek', 'Wifor', 'Wilena', 'Wilga', 'Winer', 'Wisok', and 'Wołyńska', were obtained from 8-years-old tree and hand-harvested in June and July 2016 at the Research Station for Cultivar Testing in Zybiszów near Wrocław $\left(51^{\circ} 3^{\prime} 51.11^{\prime \prime} \mathrm{N}\right.$ 
$16^{\circ} 54^{\prime} 43.56^{\prime \prime}$ E). Fruits were selected from both the interior and exterior of trees to obtain a representative sample for analysis.

\subsection{Preparation of Cloudy Sour Cherry Juices on a Laboratory Scale}

Each cvs. of sour cherry fruits $(2 \mathrm{~kg}$ ) were ground using Thermomix (Wuppertal, Vorwerk, Germany) laboratory mill for $20 \mathrm{~s}$ with an oxidation inhibitor (ascorbic acid; 1\%, v/v). After grounding, the mash was pressed in a laboratory hydraulic press (SRSE; Warsaw, Poland), and the juice was heated in the Thermomix from 20 up to $90^{\circ} \mathrm{C}$ during $4 \mathrm{~min}$, hot poured into $0.08 \mathrm{~L}$ glass jars, immediately inverted for $10 \mathrm{~min}$ to sterilize the lids, and cooled to $20^{\circ} \mathrm{C}$. Two separately technological replicates of $\mathrm{ScCJ}$ preparation were carried out. The juices directly after processing, and after 90 and 180 days of storage at $4{ }^{\circ} \mathrm{C}$ and $30^{\circ} \mathrm{C}$ were subjected to analyses.

\subsection{Identification and Quantification of Anthocyanins by LC-PDA-ESI-MS QTof and UPLC-PDA Method}

The ScCJ for identification (LC-PDA-ESI-MS QTof; Waters Corporation; Manchester, UK) and quantitative (UPLC-PDA; Waters Corporation; Milford, USA) analysis of anthocyanin compounds were performed as described previously by Wojdyło et al. [4]. Separations of anthocyanins were carried out using an Aquity BEH C18 column $(1.7 \mu \mathrm{m}, 2.1$ by $100 \mathrm{~mm}$; Waters Corporation, Milford, MA, USA) at $30{ }^{\circ} \mathrm{C}$ and injection was $5 \mu \mathrm{L}$. The mobile phase was flow at $0.42 \mathrm{~mL} / \mathrm{min}$ and composed of solvent A $(0.1 \%$ formic acid for identification analysis by LC-MS and $4.5 \%$ formic acid for quantification by UPLC-PDA analysis) and solvent B (100\% of acetonitrile with $0.1 \%$ of formic acid). The mobile phase which consisted of gradient program was as follows: $99 \%$ of A as initial conditions, $75 \%$ of A at $12 \mathrm{~min}$, $100 \%$ of B at $12.5 \mathrm{~min}$, and up to start at $13.5 \mathrm{~min}-99 \%$ of A. The injection volume of samples was $5 \mu \mathrm{L}$. PDA spectra were recorded over the wavelength range of 200-600 $\mathrm{nm}$ in steps of $2 \mathrm{~nm}$. Characterization of the single components was carried out via the retention time and the accurate molecular masses. Analyses were carried out with voltage ramping cycles from 0.3 to $2 \mathrm{~V}$, using full scan mode, and data-dependent MS scanning from $\mathrm{m} / \mathrm{z} 100$ to 1800, with collision induced fragmentation experiments were performed using argon as the collision gas. The capillary and cone voltages were $2500 \mathrm{~V}$ and $30 \mathrm{~V}$, respectively. The capillary temperature was set to $300^{\circ} \mathrm{C}$, while the source heater temperature was $100{ }^{\circ} \mathrm{C}$, and desolvation gas (nitrogen) flow rate of $300 \mathrm{~L} / \mathrm{h}$. Leucine enkephalin was flow rate of $2 \mu \mathrm{L} / \mathrm{min}$ and was used as the reference compound at a concentration of $500 \mathrm{pg} / \mu \mathrm{L}$, and $\mathrm{m} / \mathrm{z}$ at 554.2615 and 556.2771 were detected for negative and positive ionization, respectively. The mass spectrometer was operated in a positive ion mode, set to the base peak intensity (BPI) chromatograms. Analysis was carried out three times at $520 \mathrm{~nm}$ for anthocyanins, and compared with those of pure standards of cyanidin-3-O-sophoroside, -3-O-glucoside, -3-O-rutinoside, peonidin-3-O-rutinoside and pelargonidin-3-O-glucoside. Calibration curves at concentrations ranging from 0.05 to $0.5 \mathrm{mg} / \mathrm{mL}$ $\left(r^{2} \leq 0.9997\right)$. The results were expressed as $\mathrm{mg}$ per $\mathrm{L}$ of juices.

\subsection{Kinetics of Phytochemical Degradation}

The degradation kinetics of anthocyanins follows the first-order equation,

$$
C t=C o \exp ( \pm \mathrm{kt})
$$

where $C t$ and $C o$ are the concentration of bioactive compounds $(\mathrm{mg} / 100 \mathrm{~mL})$ at time $t$ and to, respectively, $\mathrm{k}$ is the rate constant, and $\mathrm{t}$ is the storage time (days). Half-life value $\left(t_{1 / 2}\right)$ was calculated as $t_{1 / 2}=(\ln 2 / \mathrm{k})$. Times required for $90 \%$ degradation of bioactive compounds ( $D$ value) was also calculated as $D=(1 / \mathrm{k})$.

\subsection{Color}

The CIE L*a* $b^{*}$ calculations represent a suitable method to describe color changes in juices during storage. Color changes during storage were determined colorimetrically by A5 Chroma-Meter (Minolta CR300, Osaka, Japan) in $20 \mathrm{~mm}$ pathway cuvettes. The system was controlled by Color-quest software. 
Values of $\mathrm{L}^{*}, \mathrm{a}^{*}$ and $\mathrm{b}^{*}$ were measured to describe a three-dimensional color space. The vertical axis $\mathrm{L}^{*}$ is a measure of lightness, where values range from completely opaque (0) to completely transparent $(100), a^{*}$ is a measure of redness (or $-a^{*}$ of greenness) and $b^{*}$ is a measure of yellowness (or $-b^{*}$ of blueness) on the hue-circle. The hue angle is corresponding to the relative amounts of redness and yellowness where $0^{\circ} 360^{\circ}$ is defined for magenta color, $90^{\circ}$ for yellow, $180^{\circ}$ for green and $270^{\circ}$ for blue. Chroma gives further information on the saturation or intensity of color.

Chroma $\left(C^{*}\right)$ and hue angle $\left(h^{\circ}\right)$ were calculated from $\mathrm{a}^{*}$ and $\mathrm{b}^{*}$ coordinates with the following equations:

$$
\begin{aligned}
& C^{*}=\left(a^{* 2}+b^{* 2}\right) \\
& h^{\circ}=\arctan \frac{b *}{a^{*}}
\end{aligned}
$$

\subsection{Statistical Analysis}

Results were presented a mean \pm standard deviation of two independent determinations. All statistical analyses were performed with Statistica version 12.0 (StatSoft, Krakow, Poland). One-way analysis of variance (ANOVA) by Duncan's test was used to compare the mean values. Differences were considered to be significant at $p<0.05$.

\section{Results and Discussion}

\subsection{Identification of Phenolic Compounds of Sour Cherry Cloudy Juices}

LC-PDA-MS QTof of analysis of ScCJ revealed the presence of anthocyanins (Table 1, Figure 1). All compounds were tentatively identified based on their UV adsorption value, $m / z$ value, retention time and elution order as compared with standards and published data $[4,6]$.

A total of five anthocyanins, four cyanidins, i.e., $-3-O$-sophoroside $\left(\mathrm{Rt}=3.69 \mathrm{~min}, \lambda_{\max }=515\right)$ with $[\mathrm{M}+\mathrm{H}]^{+}$at $m / z=611.1564$ and main MS/MS fragment at $\left.m / z=287.0536\right),-3-O$-glucosyl-rutinoside $\left(\mathrm{Rt}=3.89 \mathrm{~min}, \lambda_{\max }=517\right)$ with $[\mathrm{M}+\mathrm{H}]^{+}$at $m / z=757.2184$ and main MS/MS fragment at $\left.m / z=287.0536\right)$, -3-O-glucoside $\left(\mathrm{Rt}=4.01 \mathrm{~min}, \lambda_{\max }=516\right)$ with $[\mathrm{M}+\mathrm{H}]^{+}$at $\mathrm{m} / z=449.1063$ and main MS/MS fragment at $m / z=287.0571$ ), and -3-O-rutinoside ( $\left.\mathrm{Rt}=4.31 \mathrm{~min}, \lambda_{\max }=517\right)$ with $[\mathrm{M}+\mathrm{H}]^{+}$at $m / z=595.1664$ and main MS/MS fragment at $m / z=287.0571)$, and one peonidin-3-O-rutinoside $\left(\mathrm{Rt}=5.45 \mathrm{~min}, \lambda_{\max }=517\right)$ with $[\mathrm{M}+\mathrm{H}]^{+}$at $m / z=609.1857$ and main MS/MS fragment at $m / z=301.0730$ ) were detected in all investigated juices. These results corroborated other findings published for sour cherry fruits $[4,6,13]$.

Table 1. Identification of anthocyanins in CScJ by LC-PDA-MS QTof (Positive Mode).

\begin{tabular}{ccccc}
\hline Compound & Rt $(\mathbf{m i n})$ & $\lambda \max (\mathbf{n m})$ & {$[\mathbf{M}]+(\mathbf{m} / \mathbf{z})$} & $\begin{array}{c}\text { MS Ion Fragments } \\
(\mathrm{m} / \mathbf{z})\end{array}$ \\
\hline Cyanidin-3-O-sophoroside & 3.69 & $242 / 278 / 515$ & $611.1564+$ & $449.1063 / 287.0536$ \\
Cyanidin-3-O-glucosyl-rutinoside & 3.89 & $242 / 278 / 517$ & $757.2184+$ & $611.1614 / 433.1125 / 287.0536$ \\
Cyanidin-3-O-glucoside & 4.01 & $242 / 516$ & $449.1063+$ & 287.0571 \\
Cyanidin-3-O-rutinoside & 4.31 & $242 / 279 / 517$ & $595.1664+$ & $499.1063 / 287.0571$ \\
Peonidin-3-O-rutinoside & 5.45 & $241 / 279 / 517$ & $609.1857+$ & $301.0730 / 463.0341$ \\
\hline
\end{tabular}




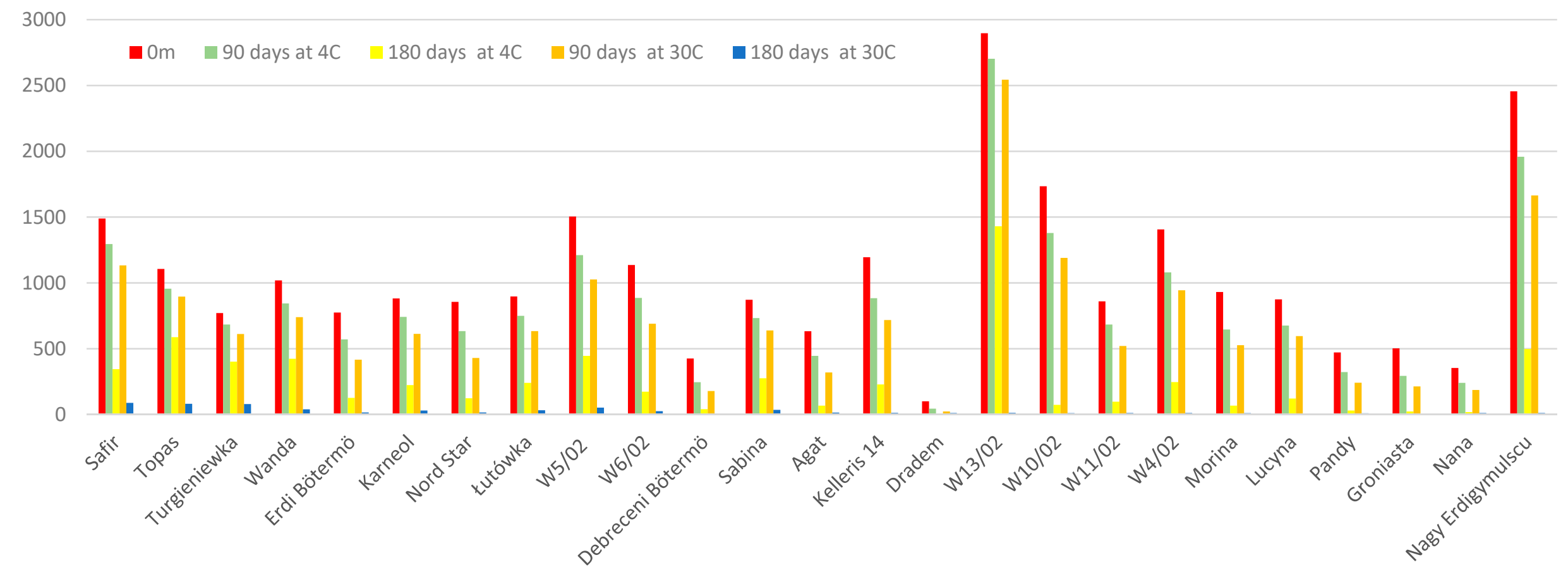

Figure 1. Sum of anthocyanins compounds content $[\mathrm{mg} / \mathrm{L}]$ in cloudy sour cherry juices after 90 and 180 days of storage time at 4 and $30{ }^{\circ} \mathrm{C}$. 


\subsection{Anthocyanins of Sour Cherry Cloudy Juices}

Anthocyanins are one of the most important phenolic compounds responsible for attractive red color of ScCJ. The color and appearance of food is the first sensory experience of consumers. Processing and especially storage time may affect color properties and appeal of food. Our study demonstrated that sour cherry juices had the same profile of anthocyanins but each compound was detected in different amount.

The results obtained for total anthocyanin content revealed significant differences among juices, with values varying from $\sim 590$ to $\sim 1160 \mathrm{mg} / \mathrm{L}$ (Table 2). The highest content of anthocyanins was found in Skierka, Nagy Erdigymulscu, Wilena, Wiblek, and Safir (up to $590 \mathrm{mg} / \mathrm{L}$ ), and the lowest in Dradem and Nana (below $100 \mathrm{mg} / \mathrm{L}$ ). Dradem and Nana juices were made from typically pink cv., and therefore the content of anthocyanins was exceptionally low. Our findings showed that total amount of anthocyanins in ScCJ was largely affected by the cultivar, as also reported by other authors $[4,6,13]$.

Table 2. Content of anthocyanins compounds $[\mathrm{mg} / \mathrm{L}]$ in cloudy sour cherry juices before storage time.

\begin{tabular}{|c|c|c|c|c|c|}
\hline \multirow{2}{*}{$\begin{array}{l}\text { Sour Cherry } \\
\text { Cloudy Juices }\end{array}$} & \multicolumn{5}{|c|}{0 Days } \\
\hline & $\mathrm{C} 3 \mathrm{~s}$ & C3gr & $\mathrm{C} 3 \mathrm{r}$ & P3r & $\mathrm{dC}+\mathrm{C} 3 \mathrm{~g}$ \\
\hline Safir & $292.21 \pm 9.20 b^{*}$ & $247.87 \pm 8.12 \mathrm{c}$ & $10.36 \pm 0.44 c$ & $44.19 \pm 1.31 \mathrm{j}$ & $1.20 \pm 0.02 \mathrm{~d}$ \\
\hline Topas & $118.99 \pm 3.75 \mathrm{~h}$ & $243.89 \pm 3.02 c$ & $8.29 \pm 0.15 \mathrm{f}$ & $69.99 \pm 2.07 \mathrm{e}, \mathrm{f}$ & $1.10 \pm 0.04 \mathrm{e}$ \\
\hline Turgieniewka & $81.8 \pm 2.58 \mathrm{j}$ & $192.52 \pm 7.15 \mathrm{f}$ & $4.67 \pm 0.15 \mathrm{k}$ & $28.89 \pm 0.861$ & $0.29 \pm 0.01 \mathrm{j}$ \\
\hline Wanda & $140.14 \pm 4.41 \mathrm{~g}$ & $200.15 \pm 4.34 \mathrm{e}$ & $9.04 \pm 0.43 \mathrm{e}$ & $57.45 \pm 1.70 \mathrm{~h}, \mathrm{i}$ & $0.94 \pm 0.04 \mathrm{f}$ \\
\hline Erdi Bötermö & $81.72 \pm 2.57 \mathrm{j}$ & $161.9 \pm 5.67 \mathrm{~g}$ & $6.17 \pm 0.05 \mathrm{i}$ & $59.79 \pm 1.77 \mathrm{~g}, \mathrm{~h}$ & $0.18 \pm 0.01 \mathrm{k}$ \\
\hline Karneol & $81.54 \pm 1.57 \mathrm{j}$ & $206.84 \pm 12.03 \mathrm{e}$ & $7.53 \pm 0.12 \mathrm{~g}$ & $56.22 \pm 1.67 \mathrm{i}$ & $0.79 \pm 0.03 \mathrm{~g}, \mathrm{~h}$ \\
\hline Nord Star & $122.76 \pm 3.87 \mathrm{~h}$ & $193.72 \pm 10.11 \mathrm{f}$ & $3.04 \pm 0.101$ & $22.36 \pm 0.66 \mathrm{~m}$ & $0.58 \pm 0.02 \mathrm{i}$ \\
\hline Łutówka & $96.54 \pm 3.04 \mathrm{i}$ & $186.86 \pm 8.03 \mathrm{f}$ & $6.78 \pm 0.12 \mathrm{~h}$ & $67.93 \pm 2.01 \mathrm{f}$ & $0.85 \pm 0.03 \mathrm{f}, \mathrm{g}$ \\
\hline Wiblek & $215.48 \pm 6.78 \mathrm{~d}$ & $257.8 \pm 9.12 c$ & $19.12 \pm 1.20 \mathrm{a}, \mathrm{b}$ & $108.02 \pm 3.20 \mathrm{c}$ & $1.49 \pm 0.06 c$ \\
\hline Wifor & $166.05 \pm 6.23 \mathrm{f}$ & $217.94 \pm 4.13 \mathrm{~d}$ & $8.34 \pm 0.33 \mathrm{f}$ & $61.27 \pm 1.82 \mathrm{~g}$ & $1.05 \pm 0.04 \mathrm{e}$ \\
\hline Debreceni Bötermö & $36.54 \pm 1.15 \mathrm{l}, \mathrm{m}$ & $96.79 \pm 5.69 \mathrm{j}$ & $2.50 \pm 0.07 \mathrm{~m}$ & $34.13 \pm 1.01 \mathrm{k}$ & $0.22 \pm 0.01 \mathrm{j}, \mathrm{k}$ \\
\hline Sabina & $66.06 \pm 1.08 \mathrm{k}$ & $215.7 \pm 6.79 \mathrm{~d}$ & $5.75 \pm 0.65 \mathrm{j}$ & $60.03 \pm 1.78 \mathrm{~g}, \mathrm{~h}$ & $1.05 \pm 0.04 \mathrm{e}$ \\
\hline Agat & $41.94 \pm 1.321$ & $136.85 \pm 5.27 \mathrm{~h}$ & $4.43 \pm 0.22 \mathrm{k}$ & $69.13 \pm 2.05 \mathrm{f}$ & $0.56 \pm 0.02 \mathrm{i}$ \\
\hline Kelleris 14 & $176.23 \pm 6.65 \mathrm{e}$ & $205.01 \pm 7.08 \mathrm{e}$ & $9.51 \pm 0.11 \mathrm{~d}$ & $86.4 \pm 2.56 \mathrm{~d}$ & $0.90 \pm 0.04 \mathrm{f}$ \\
\hline Dradem & $2.4 \pm 0.05 \mathrm{n}$ & $29.01 \pm 2.06 \mathrm{k}$ & $0.38 \pm 0.01 \mathrm{r}$ & $8.19 \pm 0.24 \mathrm{o}$ & $0.01 \pm 0.001$ \\
\hline Skierka & $631.66 \pm 20.89 a$ & $441.11 \pm 11.53 \mathrm{a}$ & $11.12 \pm 0.53 c$ & $69.25 \pm 2.05 \mathrm{f}$ & $5.82 \pm 0.03 \mathrm{a}$ \\
\hline Wilena & $268.09 \pm 10.44 c$ & $278.61 \pm 13.02 b$ & $21.38 \pm 1.12 \mathrm{a}$ & $124.05 \pm 3.68 \mathrm{~b}$ & $1.61 \pm 0.00 \mathrm{~b}$ \\
\hline Winer & $88.96 \pm 2.02 \mathrm{i}, \mathrm{j}$ & $190.18 \pm 13.15 \mathrm{f}$ & $6.79 \pm 0.13 \mathrm{~h}$ & $57.38 \pm 1.70 \mathrm{~h}, \mathrm{i}$ & $0.61 \pm 0.02 \mathrm{i}$ \\
\hline Wisok & $159.29 \pm 5.01 \mathrm{f}$ & $251.86 \pm 11.02 \mathrm{c}$ & $18.48 \pm 1.03 \mathrm{~b}$ & $131.42 \pm 3.89 \mathrm{a}$ & $1.46 \pm 0.06 \mathrm{c}$ \\
\hline Morina & $96.48 \pm 3.04 \mathrm{i}$ & $192.62 \pm 5.67 \mathrm{f}$ & $9.40 \pm 0.53 \mathrm{~d}, \mathrm{e}$ & $73.11 \pm 2.17 \mathrm{e}$ & $0.61 \pm 0.02 \mathrm{i}$ \\
\hline Lucyna & $85.76 \pm 2.70 \mathrm{j}$ & $211.39 \pm 10.34 \mathrm{~d}, \mathrm{e}$ & $7.45 \pm 0.23 \mathrm{~g}$ & $44.66 \pm 1.32 \mathrm{j}$ & $0.72 \pm 0.03 \mathrm{~h}$ \\
\hline Pandy & $36.26 \pm 0.001, \mathrm{~m}$ & $119.22 \pm 3.33 \mathrm{i}$ & $2.29 \pm 0.07 n$ & $30.58 \pm 0.911$ & $0.30 \pm 0.01 \mathrm{j}$ \\
\hline Groniasta & $38.01 \pm 1.19 \mathrm{l}, \mathrm{m}$ & $125.04 \pm 7.90 \mathrm{i}$ & $2.23 \pm 0.02 n$ & $35.49 \pm 1.05 \mathrm{k}$ & $0.28 \pm 0.01 \mathrm{j}, \mathrm{k}$ \\
\hline Nana & $1.62 \pm 0.00 \mathrm{n}$ & $20.82 \pm 3.131$ & $0.59 \pm 0.04 p$ & $0.11 \pm 0.00 \mathrm{p}$ & $0.05 \pm 0.001$ \\
\hline Nagy Erdigymulscu & $31.54 \pm 0.93 \mathrm{~m}$ & $92.86 \pm 0.67 j$ & $0.95 \pm 0.00 \mathrm{o}$ & $16.02 \pm 0.47 n$ & $0.24 \pm 0.01 \mathrm{j}, \mathrm{k}$ \\
\hline
\end{tabular}

Major individual anthocyanins in all sour cherry juices were cyanidin derivatives, particularly cyanidin-3-O-glucosyl-rutinoside (Table 2), and peonidin-3-O-rutinoside. This was consistent with other previously published reports [4-6]. As far as individual anthocyanin concentration was concerned, a significant variation was found between cloudy juices made from different cultivars of sour cherry fruits. Cyanidin-3-O-glucosyl-rutinoside constituted from 25 to $73 \%$ of total anthocyanin content. This compound was the most common in Topas, Turgieniewka, Wanda, Erdi Botermo, Karneol, Nord Star, Łutówka, Wiblek, Wifor, Sabina, Agat, Kelleris 14, Dradem, Wilena, Winer, Wisok, Morina, Lucyna, Pandy, Groniasta, and Nagy Erdigymulscu juices (60-73\% of total anthocyanins). The other major anthocyanin compounds identified in ScCJ were cyanidin-3-O-soforoside (7 to $68 \%$ of total anthocyanins) and peonidin-3-O-rutinoside (6 to $27 \%$ of total anthocyanins). ScCJ made 
from Skierka (631.66 mg/L), Wilena (268.09 mg/L), Safir (292.21 mg/L), and Wiblek $(215.48 \mathrm{mg} / \mathrm{L})$ cvs. had a high content of cyanidin-3-O-soforoside, and its lowest levels were determined in Nana $(1.62 \mathrm{mg} / \mathrm{L})$ and Dradem $(2.40 \mathrm{mg} / \mathrm{L})$ juices. The content of peonidin-3-O-rutinoside was similar to that of cyanidin-3-O-soforoside. The rest of anthocyanins (cyanidin-3-O-glucoside, -3-O-rutinoside and derivatives of cyanidin) were present in $\mathrm{ScCJ}$ in low amounts. In general, total content of anthocyanins as well as of individual glycosides was consistent with that reported by other authors $[5,13]$.

\subsection{Changes in Anthocyanins during Storage of Sour Cherry Cloudy Juices}

Our results showed that the loss of anthocyanins in $\mathrm{ScCJ}$ strongly correlated with storage time, temperature, and cultivar but not as strongly with the type of anthocyanin (aglycone type vs. sugar substituent) (Table 2, Tables S1 and S2). Anthocyanins were more stable in the products stored at low temperature. At $4{ }^{\circ} \mathrm{C}$, their average degradation degree was $30-50 \%$ after 180 days, while at $30{ }^{\circ} \mathrm{C}$ it was up to $92 \%$. The most intense degradation was observed in ScCJ made from Debreceni Bötermö, Wilena, Winer, Morina, Lucyna, and Groniasta cvs., and the least intense in Safir, Topas, Turgieniewka, Wanda, Karneol, Łutówka, Wiblek, and Sabina cvs. As reported previously by other authors [14,15], degradation rate increases along with temperature and this trend was also observed in our study. Wilkes et al. [16] found that anthocyanins decreased in a linear manner for up to five months of storage at $25^{\circ} \mathrm{C}$. Contrary to that, Hellstrom et al. [17] reported no differences in stability of chokeberry anthocyanin glycosides stored at $4{ }^{\circ} \mathrm{C}, 9^{\circ} \mathrm{C}$, and $21^{\circ} \mathrm{C}$ for three months.

An important difference between $\mathrm{ScCJ}$ anthocyanins and those found in other fruits (such as blueberry, strawberry, or grape) is their molecular structure [5]. The main anthocyanin in ScCJ is cyanidin-3-glucosyl-rutinoside, which is a tri-glycoside, while in many other fruits, predominant forms of anthocyanins are mono-glucosides [5]. Glycosylation at C-3 and C-5 positions affects the perceived color of the anthocyanin pigment: tri-glucoside derivatives are more intensely colored than di-glucosides and monoglucoside, and acylation of glucose further increases stability of the compound [18]. Anthocyanidin glycosides are generally more stable than the corresponding aglycones [18].

Therefore, as far as structure stability of anthocyanins was concerned, it was observed that their degradation during storage depended rather on the storage conditions (time and temperature) than on the type of anthocyanin compounds present in the sour cherry fruits. Cyanidin-3-O-glucosyl-rutinoside was found to be slightly more stable than the other mentioned anthocyanin compounds. Similar effects were observed by Wilkes et al. [16] in chokeberry juices. They reported that after 180 days of storage, the chokeberry juices lost $75 \%, 76 \%, 64 \%$, and $75 \%$ of cyanidin-3-galactoside, -3-glucoside, -3-arabinoside, and -3-xyloside, respectively. Mena et al. [15] pointed out that diglucosides of pomegranate juices were more stable than monoglucosides in samples stored at $5{ }^{\circ} \mathrm{C}$ ( $5 \%$ and $24 \%$ of loss, respectively). However, the same juices stored at $25^{\circ} \mathrm{C}$ showed a different trend, and monoglucosides were much more stable anthocyanins ( $48 \%$ of loss for monoglucosides vs. $56 \%$ for diglucosides).

Anthocyanins are highly unstable compounds. Their stability, apart from temperature and structure, depends on such factors as $\mathrm{pH}$, light, and the presence of accompanying substances, i.e., vitamin $\mathrm{C}$ or monomers of flavan-3-ols $[15,19,20]$. pH of the analyzed ScCJs was between 3.16 and 3.66 and the content of vitamin $\mathrm{C}$ was between 0.4 and $1.5 \mathrm{mg} / \mathrm{L}$ (data not presented). At $\mathrm{pH}$ higher than 2.0 anthocyanins are known to be thermally degraded through the formation of chalcone structure [21]. This can be associated with different forms of anthocyanin present at different $\mathrm{pH}$, e.g., flavilium cationic form of anthocyanin is common in acidic solutions, whereas in neutral conditions less stable chalcone, carbinol, and quinonoidal forms prevail.

\subsection{Kinetics of Anthocyanin Degradation during Storage of Sour Cherry Cloudy Juices}

The loss of anthocyanins during storage (Tables 2 and 3) fitted the exponential curves for the two selected temperatures (Table 4). This indicated that the pigment degradation at isothermal conditions followed first-order reaction kinetics, as usually reported for red juices [13,15,22]. Kinetic parameters revealed a significant cultivar effect on the evolution of anthocyanins during storage at both $4{ }^{\circ} \mathrm{C}$ and 
$30{ }^{\circ} \mathrm{C}$ (Table 3). Half-life periods of the anthocyanins differed depending on the cultivar and storage conditions. The rate constant $(\mathrm{k})$ increased at higher storage temperature and equaled from 0.662 to 1.929 and from 1.110 to 2.717 for $4{ }^{\circ} \mathrm{C}$ and $30^{\circ} \mathrm{C}$, respectively. This demonstrated a considerable effect of temperature on accelerated anthocyanin degradation as suggested by Alighourchi et al. [23] and Mena et al. [15]. Half-life values ( $\left.\mathrm{t}_{1 / 2}\right)$ for stored ScCJs ranged from 64.7 to 188.5 days at $4{ }^{\circ} \mathrm{C}$ and from 45.9 to 112.40 days at $30{ }^{\circ} \mathrm{C}$. It meant that the long $\mathrm{t}_{1 / 2}$ of anthocyanin degradation at $4{ }^{\circ} \mathrm{C}$ in $\mathrm{ScCJ}$ were made from Topas, Turgieniewka, Wanda, Dradem, Skierka cvs. ( $>150$ days) and the lowest for Groniasta, Pandy, and Morina cvs. ( $<80$ days). For sample stored at $30{ }^{\circ} \mathrm{C}$ the long $\mathrm{t}_{1 / 2}$ of anthocyanin degradation were evaluated for ScCJ made from Turgieniewka cv. ( $>100$ days) and the lowest for Skierka, Wilena, and Lucyna ( $<80$ days). D values denoting the time required for a degradation of $90 \%$ of ScCJ anthocyanins ranged between 95.7 and 271.9 days for juices stored at $4{ }^{\circ} \mathrm{C}$ and between 66.2 and 158.3 days at $30^{\circ} \mathrm{C}$. The highest $\mathrm{D}$ values were noticed for ScCJ made from Topas, Turgieniewka, Dradem, Skierka, Wanda, and Wilena cvs. stored at $4{ }^{\circ} \mathrm{C}$, and Turgieniewka, Topas, Safir, Wanda, Dradem, Karnelo and Sabina cvs. stored at $30^{\circ} \mathrm{C}$. The lowest D values (less than 100 days) were calculated for ScCJ made from Wilena and Groniasta cvs. stored at $4{ }^{\circ} \mathrm{C}$, and Skierka, Kelleris 14, Groniasta, and Lucyna cvs. stored at $30^{\circ} \mathrm{C}$. In general, the time to degrade $90 \%$ of anthocyanins was longer during cold storage. The same observation was made in other studies [15,24].

Kinetic parameters ( $t_{1 / 2}$ and $\mathrm{D}$ value) were clearly higher for Topas, Turgieniewka, Wanda, Wiblek, Sabina, and Łutówka cvs., regardless of storage conditions. This indicated that the stability of anthocyanins in stored ScCJ was closely associated with a cultivar and temperature. Mena at al. [15] reported that half-life values $\left(t_{1 / 2}\right)$ for pomegranate juices stored at $5{ }^{\circ} \mathrm{C}$ ranged from 98 to 374 days and from 28 to 87 days at $25^{\circ} \mathrm{C}$. D values were between 141 and 539 days for juices stored at $5^{\circ} \mathrm{C}$ and between 40 and 125 days for those stored at $25^{\circ} \mathrm{C}$. Bonerz et al. [13] claimed that half-life periods of monomeric anthocyanins varied and depended on their structure and cultivar. Similar effects were described by Mena et al. [15] and Wilkes et al. [16]. In sour cherry, the main anthocyanin is cyanidin-3-O-glucosyl-rutinoside. As for its structure stability, tri- and diglucosides seem to be more stable than monoglucosides and anthocyanin hexosides more stable than pentosides $[15,16]$. Each compound displayed its own specific decay, related to the sugar binding and the storage temperature. Moreover, it seems that the anthocyanins bound to glucose exhibited a faster degradation rate than those bound to galactose [25]. In regard to conjugated sugars, the ranking order was glucoside $>$ galactoside $>$ arabinoside from the most to the least stable. Bonerz et al. [13] demonstrated that cyanidin-3-O-glucosyl-rutinoside was the most stable pigment in sour cherry juices independent of cultivar, with a half-life period of 72-95 days, with peonidin-3-O-rutinoside showing the fastest degradation rate (29-54 days). Our outcomes confirmed that cyanidin-3-O-glucosyl-rutinoside was more stable than cyanidin-3-O-rutinosie and -3-O-soforoside that were still more stable than peonidin-3-O-rutinoside and cyanidin-3-O-glucoside.

This effect was observed for both types of storage conditions. Fracassetti et al. [25] present results where the reduction anthocyanin content of wild blueberry powder at $80^{\circ} \mathrm{C}$ was $>90 \%$ after 3 days storage only. Major parameters determining the stability of anthocyanins are water activity $\left(\mathrm{a}_{\mathrm{W}}\right)$ and water content, temperature, absence/presence of oxygen, light, and relative humidity. Additionally, this could be attributable to a matrix effect and/or a different $\mathrm{pH}$ because $\mathrm{pH}$ lower than 4.1 maintains anthocyanins stability. 
Table 3. Summary of anthocyanins compounds content $[\mathrm{mg} / \mathrm{L}]$ in cloudy sour cherry juices after 3 and 6 months of storage time at 4 and $30^{\circ} \mathrm{C}$.

\begin{tabular}{|c|c|c|c|c|c|}
\hline \multirow{2}{*}{ Sour Cherry Cloudy Juices } & \multicolumn{5}{|c|}{ Storage Condition } \\
\hline & $0 \mathrm{~m}$ & $3 \mathrm{~m}$ at $4{ }^{\circ} \mathrm{C}$ & $6 \mathrm{~m}$ at $4{ }^{\circ} \mathrm{C}$ & $3 \mathrm{~m}$ at $30^{\circ} \mathrm{C}$ & $6 \mathrm{~m}$ at $30^{\circ} \mathrm{C}$ \\
\hline Safir & $595.83 \pm 23.61 \mathrm{c}$ & $518.17 \pm 25.72 b$ & $68.87 \pm 3.89 \mathrm{e}$ & $453.19 \pm 31.55 b$ & $35.55 \pm 0.45 a$ \\
\hline Topas & $442.26 \pm 20.52 \mathrm{f}$ & $382.34 \pm 18.97 \mathrm{e}$ & $117.59 \pm 7.66 b$ & $358.43 \pm 14.96 \mathrm{~d}$ & $32.60 \pm 1.29 b$ \\
\hline Turgieniewka & $308.18 \pm 12.21 \mathrm{i}$ & $273.50 \pm 13.57 \mathrm{gh}$ & $80.27 \pm 2.18 \mathrm{~d}$ & $244.52 \pm 19.02 \mathrm{gh}$ & $31.70 \pm 0.33 b$ \\
\hline Wanda & $407.73 \pm 5.15 \mathrm{~g}$ & $337.41 \pm 26.74 \mathrm{f}$ & $84.78 \pm 2.35 \mathrm{~cd}$ & $295.99 \pm 20.61 \mathrm{e}$ & $15.59 \pm 1.51 \mathrm{~d}$ \\
\hline Erdi Bötermö & $309.76 \pm 3.85 \mathrm{i}$ & $228.46 \pm 11.33 \mathrm{i}$ & $25.30 \pm 1.00 \mathrm{i}$ & $166.56 \pm 9.59 j$ & $6.12 \pm 0.24 \mathrm{~h}$ \\
\hline Karneol & $352.93 \pm 15.98 \mathrm{~h}$ & $296.72 \pm 14.72 \mathrm{~g}$ & $44.71 \pm 1.77 \mathrm{~g}$ & $245.05 \pm 12.06 \mathrm{gh}$ & $12.06 \pm 0.47 \mathrm{f}$ \\
\hline Nord Star & $342.45 \pm 13.57 \mathrm{~h}$ & $253.37 \pm 12.57 \mathrm{hi}$ & $24.65 \pm 1.65 \mathrm{i}$ & $171.82 \pm 13.96 \mathrm{ij}$ & $6.00 \pm 0.13 \mathrm{hi}$ \\
\hline Łutówka & $358.96 \pm 4.22 \mathrm{~h}$ & $299.88 \pm 4.88 \mathrm{~g}$ & $48.13 \pm 2.90 \mathrm{~g}$ & $253.43 \pm 7.64 \mathrm{fg}$ & $12.96 \pm 0.31 \mathrm{f}$ \\
\hline Wiblek & $601.92 \pm 34.85 c$ & $484.53 \pm 14.04 \mathrm{c}$ & $89.15 \pm 4.53 c$ & $410.37 \pm 28.57 \mathrm{c}$ & $20.91 \pm 0.02 c$ \\
\hline Wifor & $454.64 \pm 8.18$ ef & $354.35 \pm 17.58 \mathrm{f}$ & $34.67 \pm 0.37 \mathrm{~h}$ & $276.07 \pm 22.32 \mathrm{efg}$ & $10.30 \pm 0.41 \mathrm{~g}$ \\
\hline Debreceni Bötermö & $170.17 \pm 7.74 \mathrm{~lm}$ & $98.16 \pm 4.87 \mathrm{kl}$ & $8.02 \pm 0.311$ & $71.26 \pm 7.961$ & $2.57 \pm 0.00 \mathrm{~m}$ \\
\hline Sabina & $348.60 \pm 16.81 \mathrm{~h}$ & $293.29 \pm 14.55 \mathrm{~g}$ & $55.17 \pm 5.01 \mathrm{f}$ & $255.46 \pm 13.78 \mathrm{fg}$ & $13.97 \pm 0.05 \mathrm{e}$ \\
\hline Agat & $252.92 \pm 5.68 j$ & $178.06 \pm 5.22 j$ & $13.41 \pm 0.53 \mathrm{k}$ & $127.76 \pm 5.89 \mathrm{k}$ & $5.77 \pm 0.23 \mathrm{hij}$ \\
\hline Kelleris 14 & $478.05 \pm 33.94 \mathrm{e}$ & $353.48 \pm 11.54 \mathrm{f}$ & $45.64 \pm 0.80 \mathrm{~g}$ & $287.29 \pm 17.18$ ef & $4.95 \pm 0.19 \mathrm{ik}$ \\
\hline Dradem & $39.99 \pm 3.58 \mathrm{n}$ & $17.91 \pm 1.12 \mathrm{~m}$ & $0.48 \pm 0.02 \mathrm{n}$ & $9.40 \pm 0.65 \mathrm{~m}$ & $4.34 \pm 0.171$ \\
\hline Skierka & $1158.95 \pm 33.92 \mathrm{a}$ & $1081.28 \pm 43.66 \mathrm{a}$ & $286.05 \pm 3.33 \mathrm{a}$ & $1017.49 \pm 70.84 a$ & $5.06 \pm 0.211$ \\
\hline Wilena & $693.75 \pm 44.49 \mathrm{~b}$ & $551.80 \pm 33.38 b$ & $14.64 \pm 0.98 \mathrm{k}$ & $476.24 \pm 13.16 b$ & $4.11 \pm 0.091$ \\
\hline Winer & $343.92 \pm 23.62 \mathrm{~h}$ & $273.53 \pm 3.57 \mathrm{gh}$ & $19.48 \pm 0.07 j$ & $208.28 \pm 14.50 \mathrm{hi}$ & $4.53 \pm 0.311$ \\
\hline Wisok & $562.51 \pm 12.12 \mathrm{~d}$ & $431.91 \pm 11.45 \mathrm{~d}$ & $49.36 \pm 2.95 \mathrm{~g}$ & $377.79 \pm 29.31 \mathrm{~cd}$ & $4.50 \pm 0.071$ \\
\hline Morina & $372.23 \pm 14.75 \mathrm{~h}$ & $258.45 \pm 9.82 \mathrm{hi}$ & $13.45 \pm 0.44 \mathrm{k}$ & $210.86 \pm 16.68 \mathrm{hi}$ & $4.03 \pm 0.161$ \\
\hline Lucyna & $349.98 \pm 9.87 \mathrm{~h}$ & $270.18 \pm 11.41 \mathrm{gh}$ & $24.38 \pm 0.56 \mathrm{i}$ & $238.36 \pm 11.59 \mathrm{gh}$ & $1.90 \pm 0.05 n$ \\
\hline Pandy & $188.66 \pm 9.47 \mathrm{kl}$ & $128.91 \pm 7.39 \mathrm{k}$ & $6.01 \pm 0.871$ & $96.47 \pm 6.71 \mathrm{kl}$ & $3.65 \pm 0.151$ \\
\hline Groniasta & $201.05 \pm 8.96 \mathrm{k}$ & $117.28 \pm 9.03 \mathrm{kl}$ & $4.67 \pm 0.07 \mathrm{~lm}$ & $85.20 \pm 5.931$ & $1.58 \pm 0.06 n$ \\
\hline Nana & $23.18 \pm 1.91 \mathrm{n}$ & $10.85 \pm 0.53 \mathrm{~m}$ & $0.50 \pm 0.10 \mathrm{n}$ & $7.74 \pm 1.13 \mathrm{~m}$ & $3.76 \pm 0.091$ \\
\hline Nagy Erdigymulscu & $141.61 \pm 10.61 \mathrm{~m}$ & $96.05 \pm 4.761$ & $3.73 \pm 0.33 \mathrm{~lm}$ & $74.75 \pm 7.201$ & $4.49 \pm 0.211$ \\
\hline
\end{tabular}


Table 4. Kinetic parameters of anthocyanin degradation in cloudy sour cherry juices during storage at different temperatures.

\begin{tabular}{|c|c|c|c|c|c|c|c|c|c|c|}
\hline \multirow{2}{*}{$\begin{array}{l}\text { Sour Cherry } \\
\text { Cloudy Juices }\end{array}$} & \multicolumn{5}{|c|}{ Stability of Anthocyanins of ScCJ Storage at $4{ }^{\circ} \mathrm{C}$} & \multicolumn{5}{|c|}{ Stability of Anthocyanins of $\mathrm{ScCJ}$ Storage at $30^{\circ} \mathrm{C}$} \\
\hline & $\begin{array}{c}\text { Variation Kinetics } \\
\text { (Concentration in } \mathrm{mg} / \mathrm{L} \text { ) }\end{array}$ & $\mathbf{R}^{2}$ & $\begin{array}{l}-\mathrm{k} \times 10^{3} \\
\left(\mathrm{Day}^{-1}\right)\end{array}$ & $\begin{array}{l}t_{1 / 2} \\
\text { (Day) }\end{array}$ & $\begin{array}{l}\text { D Value } \\
\text { (Day) }\end{array}$ & $\begin{array}{c}\text { Variation Kinetics } \\
\text { (Concentration in } \mathrm{mg} / \mathrm{L} \text { ) }\end{array}$ & $\mathbf{R}^{2}$ & $\begin{array}{r}-k \times 10^{3} \\
\left(\text { Day }^{-1}\right)\end{array}$ & $\begin{array}{c}t_{1 / 2} \\
\text { (Day) }\end{array}$ & $\begin{array}{l}\text { D Value } \\
\text { (Day) }\end{array}$ \\
\hline Safir & $2396.794 \mathrm{e}^{-1079 x}$ & 0.798 & 1.079 & 115.7 & 166.8 & $3562.000 \mathrm{e}^{-1.410 \mathrm{x}}$ & 0.822 & 1.410 & 88.5 & 127.7 \\
\hline Topas & $1018.920 \mathrm{e}^{-0.662 \mathrm{x}}$ & 0.831 & 0.662 & 188.5 & 271.9 & $2345.462 \mathrm{e}^{-1.304 \mathrm{x}}$ & 0.810 & 1.304 & 95.7 & 138.0 \\
\hline Turgieniewka & $726.152 e^{-0.673 x}$ & 0.816 & 0.673 & 185.4 & 267.5 & $1299.585 \mathrm{e}^{-1.137 \mathrm{x}}$ & 0.825 & 1.137 & 109.8 & 158.3 \\
\hline Wanda & $1090.651 \mathrm{e}^{-0.785 \mathrm{x}}$ & 0.839 & 0.785 & 159.0 & 229.3 & $3228.664 \mathrm{e}^{-1.632 \mathrm{x}}$ & 0.823 & 1.632 & 76.5 & 110.3 \\
\hline Erdi Bötermö & $1486.698 \mathrm{e}^{-1.252 \mathrm{x}}$ & 0.840 & 1.252 & 99.7 & 143.8 & $3446.582 \mathrm{e}^{-1.962 \mathrm{x}}$ & 0.865 & 1.962 & 63.6 & 91.7 \\
\hline Karneol & $1320.599 \mathrm{e}^{-1.033 \mathrm{x}}$ & 0.812 & 1.033 & 120.8 & 174.2 & $2967.864 \mathrm{e}^{-1.688 \mathrm{x}}$ & 0.830 & 1.688 & 73.9 & 106.6 \\
\hline Nord Star & $1789.955 \mathrm{e}^{-1.316 \mathrm{x}}$ & 0.835 & 1.316 & 94.8 & 136.8 & $4033.887 \mathrm{e}^{-2.022 \mathrm{x}}$ & 0.874 & 2.022 & 61.7 & 89.0 \\
\hline Łutówka & $1290.502 \mathrm{e}^{-1.005 \mathrm{x}}$ & 0.817 & 1.005 & 124.2 & 179.1 & $2925.961 \mathrm{e}^{-1.661}$ & 0.828 & 1.661 & 75.1 & 108.4 \\
\hline Wiblek & $2000.217 e^{-0.955 x}$ & 0.834 & 0.955 & 130.7 & 188.5 & $4975.945 \mathrm{e}^{-1.680 \mathrm{x}}$ & 0.834 & 1.680 & 74.3 & 107.1 \\
\hline Wifor & $2326.683 e^{-1.287 x}$ & 0.822 & 1.287 & 97.0 & 139.9 & $4808.504 e^{-1.894 x}$ & 0.847 & 1.894 & 65.9 & 95.0 \\
\hline Debreceni Bötermö & $1085.732 e^{-1.527 x}$ & 0.880 & 1.527 & 81.7 & 117.9 & $2083.786 \mathrm{e}^{-1.096}$ & 0.898 & 2.096 & 59.5 & 85.9 \\
\hline Sabina & $1124.793 \mathrm{e}^{-0.922}$ & 0.820 & 0.922 & 135.4 & 195.2 & $2683.797 e^{-1.609 x}$ & 0.822 & 1.609 & 77.6 & 111.9 \\
\hline Agat & $1594.207 \mathrm{e}^{-1.469 \mathrm{x}}$ & 0.838 & 1.469 & 85.0 & 122.5 & $2504.111 \mathrm{e}^{-1.890 \mathrm{x}}$ & 0.880 & 1.890 & 66.0 & 95.2 \\
\hline Kelleris 14 & $2069.460 \mathrm{e}^{-1.174 \mathrm{x}}$ & 0.845 & 1.174 & 106.3 & 153.3 & $8491.887 \mathrm{e}^{-2.285 \mathrm{x}}$ & 0.832 & 2.285 & 54.6 & 78.8 \\
\hline Dradem & $74.718 \mathrm{e}^{-0.670 \mathrm{x}}$ & 0.987 & 0.670 & 186.3 & 268.7 & $108.484 \mathrm{e}^{-1.110 \mathrm{x}}$ & 0.970 & 1.110 & 112.4 & 162.2 \\
\hline Skierka & $2878.102 e^{-0.700 x}$ & 0.787 & 0.700 & 178.3 & 257.1 & $41542.963 e^{-2.717}$ & 0.768 & 2.717 & 45.9 & 66.2 \\
\hline Wilena & $8417.307 \mathrm{e}^{-1.929 \mathrm{x}}$ & 0.794 & 1.929 & 64.7 & 93.3 & $18691.851 \mathrm{e}^{-2.564 \mathrm{x}}$ & 0.805 & 2.564 & 48.7 & 70.2 \\
\hline Winer & $2160.469 \mathrm{e}^{-1.436 \mathrm{x}}$ & 0.809 & 1.436 & 86.9 & 125.3 & $5216.958 e^{-2.165 x}$ & 0.836 & 2.165 & 57.6 & 83.1 \\
\hline Wisok & $2608.467 e^{-1.217 x}$ & 0.830 & 1.217 & 102.5 & 147.9 & $12315.356 \mathrm{e}^{-2.414 \mathrm{x}}$ & 0.811 & 2.414 & 51.7 & 74.6 \\
\hline Morina & $3015.725 e^{-1.660 x}$ & 0.831 & 1.660 & 75.2 & 108.4 & $6293.191 e^{-2.263 x}$ & 0.843 & 2.263 & 55.1 & 79.5 \\
\hline Lucyna & $1896.350 \mathrm{e}^{-1.332 \mathrm{x}}$ & 0.822 & 1.332 & 93.7 & 135.1 & $9968.625 \mathrm{e}^{-2.608 \mathrm{x}}$ & 0.805 & 2.608 & 47.9 & 69.0 \\
\hline Pandy & $1652.523 e^{-1.723 x}$ & 0.832 & 1.723 & 72.4 & 104.5 & $2093.303 e^{-1.973 x}$ & 0.873 & 1.973 & 63.3 & 91.2 \\
\hline Groniasta & $2063.496 \mathrm{e}^{-1.881 \mathrm{x}}$ & 0.855 & 1.881 & 66.3 & 95.7 & $3820.415 e^{-2.423 x}$ & 0.878 & 2.423 & 51.5 & 74.3 \\
\hline Nana & $60.841 \mathrm{e}^{-0.914 \mathrm{x}}$ & 0.991 & 0.914 & 136.5 & 196.9 & $207.602 \mathrm{e}^{-1.918 \mathrm{x}}$ & 0.942 & 1.918 & 65.1 & 93.8 \\
\hline Nagy Erdigymulscu & $589.538^{-1.167 x}$ & 0.871 & 1.167 & 106.9 & 154.2 & $1142.455 \mathrm{e}^{-1.726 \mathrm{x}}$ & 0.883 & 1.726 & 72.3 & 104.3 \\
\hline
\end{tabular}




\subsection{Changes in Color Quality During ScCJ Storage}

Color of a beverage is of paramount importance as it is the first property to be noticed and one of the main ways of visual assessment of food before consumption. The perceived color provides an indication of the expected taste and quality of food [26]. Each anthocyanin has a particular hue, ranging from red to blue. Cyanidin derivatives, main anthocyanins of sour cherry juice are associated with reddish shades.

Color parameters differed significantly $(p<0.05)$ among ScCJs and storage times (Table S3). In general, a considerable general decrease in redness (CIEa*) was observed for all sour cherry juices during storage. Redness of ScCJ before storage varied from 0.9 to 6.35. The most intense light red color was found in the ScCJ made from Dradem (6.35), Nana (5.48), Nagy Erdigymulscu (5.22), and Karneol (4.56) cvs. and it was the least intense in the juices made from Wiblek (0.9) and Skierka (1.09) cvs. In juices stored at $4{ }^{\circ} \mathrm{C}, \mathrm{CIEa}{ }^{*}$ values remained fairly stable, especially after 90 days of storage and a significant change occurred at the end of storage at $30^{\circ} \mathrm{C}$. After 90 days of storage redness slightly $(p>0.05)$ increased in some $\mathrm{ScCJ}$ samples. At $30^{\circ} \mathrm{C} \mathrm{a}^{*}$ values significantly decreased $(p<0.05)$ and ranged from 3.25 to 0.66 and from 3.54 to 0.18 after three and 180 days, respectively. The change of redness in the samples stored at $4{ }^{\circ} \mathrm{C}$ was slower, and amounted from 9.83 to 0.74 , and from 6.94 to 0.86 for 90 and 180 days, respectively. ScCJ made from Dradem, Morina and Nana cvs. showed the highest lightness, whereas the juice from Wilena cv. displayed the lowest one. Only a slight change in CIEL* parameter was observed over the entire storage period. Taking into account both redness $\left(\mathrm{CIEa}^{*}\right)$ and yellowness $\left(\mathrm{CIEb}^{*}\right)$, a similar trend was found for all the samples. Contrary to redness, little variation was observed in yellowness $\left(\mathrm{CIEb}^{*}\right)$. Pilando et al. [27] reported a strong negative correlation of both values with total anthocyanins, and suggested that the increased $L^{*}$ and $b^{*}$ resulted from anthocyanin loss. The increase in lightness and decrease in redness were in accordance with the trend followed by red color products made from pomegranate [15,28] maqui [29], and aronia [30] juices or other beverages rich in anthocyanins in a model system [31].

Chroma value and hue angle remained more stable than $\mathrm{a}^{*}$ and $\mathrm{b}^{*}$ in all samples, without notable differences after storage at $4{ }^{\circ} \mathrm{C}$, especially after 90 days. These parameters decreased by half for ScCJ stored at $30^{\circ} \mathrm{C}$. However, the rate of browning, determined by hue angle values (less than $20^{\circ}$ difference between initial and end values), was much slower than the rate of anthocyanin degradation, as reported in other red beverages [29]. This could be explained by the fact that regardless of anthocyanin loss during shelf life, red coloration of all ScCJs remained stable during the first 90 days of storage as a result of likely formation of other colored polymers, or copigmentation between anthocyanins and other flavonoids that appreciably preserved color and masked the detrimental changes during storage in the anthocyanins [32]. Despite the loss in total anthocyanin content over the storage period, red color remained stable until the end of the storage as a result of copigmentation between anthocyanins and flavonols that could also modify the color expression by changing tone shift towards purple tonalities over time as previously observed for red wine sample [33], and chokeberry juice [16]. The same effect was repeatedly reported by González-Molina et al. [28,30] and Wojdyło et al. [34] for juices made from aronia, pomegranate and maqui fruits. However, it is also possible that the anthocyanin polymers of flavan-3-ols formed in the juices during processing were more resistant to degradation during storage.

Likewise, to determine a relationship between the anthocyanin levels and color parameters of ScCJ, Person correlation test was carried out. CIEL ${ }^{*} \mathrm{a}^{*}$, and $\mathrm{b}^{*}$ negatively correlated with total anthocyanin level ( $\mathrm{r}=-0.699, \mathrm{r}=-0.685$ and $\mathrm{r}=-0.657$, respectively), as well as with Chroma and hue angle, which showed the strongest negative correlation $(r=-0.672$ and $r=-0.768)$. A significant but weaker correlation was determined for anthocyanins in the samples stored at $4{ }^{\circ} \mathrm{C}(\mathrm{r}=-0.594 ; \mathrm{r}=-0.664$, $\mathrm{r}=-0.615$ between anthocyanins and $\mathrm{L}^{*}, \mathrm{a}^{*}, \mathrm{~b}^{*}$ parameters, respectively). Not significant and the weakest correlation was identified for the samples stored for 180 days. A similar tendency was found in the samples stored at $30^{\circ} \mathrm{C}$ but the correlation values were lower. Therefore, color parameters might be taken into account as anthocyanin content indicator in $\mathrm{ScCJs}$, especially for the samples 
before storage or stored for 90 days. After 180 days of storage lower correlations suggested that other ingredients of $\mathrm{ScCJ}$ than anthocyanin were affected by the color.

\section{Conclusions}

The investigated $\mathrm{ScCJ}$ were characterized by high content of anthocyanins which may have direct implications on juice industry and help to solve browning problems during juice storage. The content of anthocyanins and color parameters load for ScC juices were mainly influenced by cultivar. The dominant anthocyanin was cyanidin-3-glucosyl-rutinoside (25-75\%). Total anthocyanin content differed significantly between juices, with values varying from $\sim 590$ to $\sim 1160 \mathrm{mg} / \mathrm{L}$. ScCJ made from Skierka, Nagy Erdigymulscu, Wilena, Wiblek, and Safircvs had the highest content of anthocyanins. Degradation of anthocyanins during the juice storage depended rather on the storage conditions (time and temperature) than on the type of anthocyanin compounds present. Kinetic parameters revealed a significant cultivar effect on the evolution of anthocyanins during storage at both $4{ }^{\circ} \mathrm{C}$ and $30^{\circ} \mathrm{C}$. Half-life value of the anthocyanins differed and depended on the cultivar and storage conditions. Half-life values of ScCJ ranged from 64.7 to 188.5 days at $4{ }^{\circ} \mathrm{C}$ and from 45.9 to 112.40 at $30{ }^{\circ} \mathrm{C}$. Redness of the samples changed more rapidly than yellowness or lightness and Chroma or hue angel. Summing up, the study results may have direct implications for the juice industry as they address problems with deterioration of attractiveness of sour cherry cloudy juices due to loss of anthocyanins and browning during storage. Further studies on bioavailability are necessary to evaluate possible benefits of sour cherry cloudy juices for human health.

Supplementary Materials: The following are available online at http://www.mdpi.com/2227-9717/7/6/367/s1, Table S1: Content of anthocyanins compounds $[\mathrm{mg} / \mathrm{L}]$ in cloudy sour cherry juices after 180 days of storage time. Table S2: Content of anthocyanins compounds $[\mathrm{mg} / \mathrm{L}]$ in cloudy sour cherry juices after 180 days of storage time. Table S3. Evolution of color parameters in sour cherry cloudy juices through storage time (180 days) at 4 and $30^{\circ} \mathrm{C}$.

Author Contributions: Conceptualization: A.W.; Collected sample: A.W.; Performed the experiments: A.W., M.T., P.N.; Analyzed the data: A.W., PN; Contributed reagents/materials/analysis tools: A.W.; Wrote the paper: A.W.; Review \& editing: A.W. Supervision: A.W.; project administration: A.W.; funding acquisition: A.W., P.N,

Funding: This research was funded by the National Science Centre UMO2011/01/B/NZ9/07139. Publication supported by Wroclaw Centre of Biotechnology, programme The Leading National Research Centre (KNOW) for years 2014-2018.

Acknowledgments: Authors thanks for Piotr Laskowski from Research Station for Cultivar Testing in Zybiszów near Wrocław from plant materials for research. Authors thanks for Emilia Maliszek for laboratory help.

Conflicts of Interest: The authors declare no conflict of interest. The funders had no role in the design of the study; in the collection, analyses, or interpretation of data; in the writing of the manuscript, or in the decision to publish the results.

\section{References}

1. Faostat, Food and Agriculture Organization of the United Nations. Food and Agricultural Commodities Production, Countries by Commodity. Available online: http://faostat.fao.org/site/339/default.aspx (accessed on 20 September 2017).

2. Mihalev, K.; Schieber, A.; Mollov, P.; Carle, R. Effect of mash maceration on the polyphenolic content and visual quality attributes of cloudy apple juice. J. Agric. Food Chem. 2004, 52, 7306-7310. [CrossRef] [PubMed]

3. Teleszko, M.; Nowicka, P.; Wojdyło, A. Effect of cultivar and storage temperature on identification and stability of polyphenols in strawberry cloudy juices. J. Food Compos. Anal. 2016, 54, 10-19. [CrossRef]

4. Wojdyło, A.; Nowicka, P.; Laskowski, P.; Oszmiański, J. Evaluation of sour cherry (Prunus cerasus L.) fruits for their polyphenol content, antioxidant properties and nutritional components. J. Agric. Food Chem. 2014, 62, 12332-12345. [CrossRef] [PubMed]

5. Toydemir, G.; Capanoglu, E.; Gomez Roldan, M.V.; De Vos, R.C.H.; Boyacioglu, D.; Hall, R.D.; Beekwilder, J. Industrial processing effects on phenolic compounds in sour cherry (Prunus cerasus L.) fruit. Food Res. Int. 2013, 53, 218-225. [CrossRef] 
6. Kołodziejczyk, K.; Sójka, M.; Abadias, M.; Viñas, I.; Guyot, S.; Baron, A. Polyphenol composition, antioxidant capacity, and antimicrobial activity of the extracts obtained from industrial sour cherry pomace. Ind. Crops Prod. 2013, 51, 279-288. [CrossRef]

7. He, J.; Giusti, M.M. Anthocyanins: Natural colorants with health promoting properties. Ann. Rev. Food Sci. Technol. 2010, 1, 163-187. [CrossRef] [PubMed]

8. Wu, X.; Beecher, G.R.; Holden, J.M.; Haytowitz, D.B.; Gebhardt, S.E.; Prior, R.L. Concentrations of anthocyanins in common foods in the United States and estimationof normal consumption. J. Agric. Food Chem. 2006, 54, 4069-4075. [CrossRef] [PubMed]

9. Heinonen, M. Antioxidant activity and antimicrobial effect of berry phenolics: A Finnish perspective. Mol. Nutr. Food Res. 2007, 51, 684-691. [CrossRef] [PubMed]

10. Wrolstad, R.E.; Skrede, G.; Lea, P.; Enersen, G. Influence of sugar on anthocyanin pigment stability in frozen strawberries. J. Food Sci. 1990, 55, 1064-1065. [CrossRef]

11. Damar, I.; Eks, A. Antioxidant capacity and anthocyanin profile of sour cherry (Prunus cerasus L.) juice. Food Chem. 2012, 135, 2910-2914. [CrossRef]

12. Kim, D.-O.; Padilla-Zakour, O.I. Jam processing effect on phenolics and antioxidant capacity in anthocyanin-rich fruits: Cherry, plum, and raspberry. J. Food Sci. 2004, 69, S395-S400. [CrossRef]

13. Bonerz, D.; Wurth, K.; Dietrich, H.; Will, F. Analytical characterization and the impact of ageing on anthocyanin composition and degradation in juices from five sour cherry cultivars. Eur. Food Res. Technol. 2007, 224, 355-364. [CrossRef]

14. Zhang, Y.; Hu, X.S.; Chen, F.; Wu, J.H.; Liao, X.J.; Wang, Z.F. Stability and colour characteristics of PEF-treated cyanidin-3-glucoside during storage. Food Chem. 2008, 106, 669-676. [CrossRef]

15. Mena, P.; Martí, N.; García-Viguera, C. Varietal blends as a way of optimizing and preserving the anthocyanin content of pomegranate (Punica granatum L.) juices. J. Agric. Food Chem. 2014, 62, 6936-6943. [CrossRef] [PubMed]

16. Wilkes, K.; Howard, L.R.; Brownmiller, C.; Prior, R.L. Changes in chokeberry (Aronia melanocarpa L.) polyphenols during juice processing and storage. J. Agric. Food Chem. 2014, 62, 4018-4025. [CrossRef] [PubMed]

17. Hellstrom, J.; Mattila, P.; Karjalainen, R. Stability of anthocyanins in berry juices stored at different temperatures. J. Food Compos. Anal. 2013, 31, 12-19.

18. Flamini, R.; Mattivi, F.; De Rosso, M.; Arapitsas, P.; Bavaresco, L. Advanced knowledge of three important classes of grape phenolics: anthocyanins, stilbenes and flavonols. Int. J. Mol. Sci. 2013, 14, 19651-19669. [CrossRef] [PubMed]

19. Ochoa, M.R.; Kesseler, A.G.; Vullioud, M.B.; Lozano, J.E. Physical and chemical characteristics of raspberry pulp: storage effect on composition and color. LWT-Food Sci. Technol. 1999, 32, 149-153. [CrossRef]

20. Eiro, M.J.; Heinonen, M. Anthocyanin color behavior and stability during storage: effect of inter molecular copigmentation. J. Agric. Food Chem. 2002, 50, 7461-7466. [CrossRef] [PubMed]

21. Sadilova, E.; Stintzing, F.C.; Carle, R. Thermal degradation of acylated and nonacylatedanthocyanins. J. Food Sci. 2006, 71, C504-C512. [CrossRef]

22. Maskan, M. Production of pomegranate (Punica granatum L.) juice concentrate by various heating methods: Colour degradation and kinetics. J. Food Eng. 2006, 72, 218-224. [CrossRef]

23. Alighourchi, H.; Barzegar, M. Some physicochemical characteristics and degradation kinetic of anthocyanin of reconstituted pomegranate juice during storage. J. Food Eng. 2009, 90, 179-185. [CrossRef]

24. Cano-Lamadrid, M.; Trigueros, L.; Wojdyło, A.; Carbonell-Barrachina, A.A.; Sendra, E. Anthocyanins decay in pomegranate enriched fermented milks as a function of bacterial strain and processing conditions. LWT_Food Sci. Technol. 2017, 80, 193-199. [CrossRef]

25. Fracassetti, D.; Del Bo, C.; Simonetti, P.; Gardana, C.; Klimis-Zacas, D.; Ciappellano, S. Effect of time and storage temperature on anthocyanin decay and antioxidant activity in wild blueberry (Vaccinium angustifolium) powder. J. Agric. Food Chem. 2013, 61, 2999-3005. [CrossRef] [PubMed]

26. Iliopoulou, I.; Thaeron, D.; Baker, A.; Jones, A.; Robertson, N. Analysis of the thermal degradation of the individual anthocyanin compounds of blackcarrot (Daucus carota L.): A new approach using high-resolution proton nuclear magnetic resonance spectroscopy. J. Agric. Food Chem. 2015, 63, 7066-7073. [CrossRef] [PubMed] 
27. Pilando, L.S.; Wrolstad, R.E.; Heatherbell, D.A. Influence of fruit composition, maturity and mold contamination on the color and appearance of strawberry wine. J. Food Sci. 1985, 50, 1121-1127. [CrossRef]

28. González-Molina, E.; Moreno, D.A.; García-Viguera, C. A new drink rich in healthy bioactives combining lemon and pomegranate juices. Food Chem. 2009, 115, 1364-1372. [CrossRef]

29. Gironés-Vilaplana, A.; Mena, P.; García-Viguera, C.; Moreno, D.A. A novel beverage rich in antioxidant phenolics: Maquiberry (Aristotelia chilensis) and lemon juice. LWT-Food Sci. Technol. 2012, 47, 279-286.

30. González-Molina, E.; Moreno, D.A.; García-Viguera, C. Aronia-enriched lemon juice: A new highly antioxidant beverage. J. Agric. Food Chem. 2008, 56, 11327-11333. [CrossRef]

31. Hernańdez-Herrero, J.A.; Frutos, M.J. Degradation kinetics of pigment, colour and stability of the antioxidant capacity in juice model systems from six anthocyanin sources. Int. J. Food Sci. Technol. 2011, 46, 2550-2557. [CrossRef]

32. Boulton, R. The copigmentation of anthocyanins and its role in the color of redwine: A critical review. Am. J. Enol. Vitic. 2001, 52, 67-87.

33. González-Manzano, S.; Dueñas, M.; Rivas-Gonzalo, J.C.; Escribano-Bailón, M.T.; Santos-Buelga, C. Studies on the copigmentation between anthocyanins and flavan-3-ols and their influence in the colour expression of red wine. Food Chem. 2009, 114, 649-656. [CrossRef]

34. Wojdyło, A.; Teleszko, M.; Oszmiański, J. Antioxidant property and storage stability of quince juice phenolic compounds. Food Chem. 2014, 152, 261-270. [CrossRef] [PubMed]

(C) 2019 by the authors. Licensee MDPI, Basel, Switzerland. This article is an open access article distributed under the terms and conditions of the Creative Commons Attribution (CC BY) license (http://creativecommons.org/licenses/by/4.0/). 